\title{
Effectiveness of Shrink-wrap Packaging on Extending the Shelf-life of Apple
}

\author{
Abhay Kumar Thakur ${ }^{\text {* }}$, Ramesh Kumar², \\ Vidya Bhushan Shambhu ${ }^{1}$ and Indu Shekhar Singh ${ }^{3}$ \\ ${ }^{1}$ ICAR-NIRJAFT, 12 Regent Park, Kolkata, India \\ ${ }^{2}$ ICAR-CIPHET, Abohar, Punjab, India \\ ${ }^{3}$ ICAR-RCER, RCM, Darbhanga, Bihar, India \\ *Corresponding author
}

\section{Keywords \\ Apple, Shrink-wrap, \\ Tray shrink-wrap, \\ Storage, Quality, \\ Marketable shelf \\ life. \\ Article Info \\ Accepted: \\ 17 October 2017 \\ Available Online: \\ 10 December 2017}

\section{A B S T R A C T}

Packaging of individual apple fruit is needed not only to improve the consumer preference but also to protect post-harvest quality during distribution and marketing. The effectiveness of polymeric shrink-wrap to individual fruit and 3 fruit in a tray-wrap was studied as packaging option for retail marketing. The shrink wrapped apples with 15 and 25 micron film were stored for 4 weeks at ambient condition $\left(30-38^{\circ} \mathrm{C}, 52-58 \% \mathrm{RH}\right)$ and evaluated for physico-chemical quality in comparison to the apples having no wrap. The changes in quality was determined by visual observation, weight loss due to desiccation, change in firmness, titrable acidity, total soluble solids, water activity, decay, colour and sensory test. Unwrapped apples were found unacceptable after two weeks due to undesirable loss in physiological weight, colour and firmness; and shriveling of the surface of the fruits. The colour and firmness of the wrapped fruits remained almost unaltered during the period of storage. The study indicated that 25 micron shrinkable film performed comparatively better than 15 micron for wrapping of apple fruit either individually or in a tray of 3 fruits. Cost analysis of shrink wrapping of individual apple fruit and 3 fruits in a tray revealed that it was not more than Rs. $0.50-0.60$ per individual fruit and Rs. 1.50 2.00 per tray of 3 fruits. The polymeric shrink-wrapping endows a safe protective coating over the fruit surface that facilitates extension of marketable shelf-life of apples by at least two weeks as compared to unwrapped fruits.

\section{Introduction}

The importance of apple fruit in daily diet from nutritional and medicinal point of view is evident from ancient literatures. An average of 2.49 million tons per year of output (Indian Horticulture Database-2014), India accounts for about $2.8 \%$ of world apple production. However, owing to the existence of a very large domestic market, India has not been very successful in exports of apples; its contribution to the world trade is only $0.15 \%$. India exports apples mostly to Bangladesh and Sri Lanka (99\% of India's apple exports). In apple, 7 size grades have been prescribed with suitable dimensions of packing boxes, size of wrapping papers and number of layers of fruits for each grade has been standardized for domestic market and export.

Polymeric film bags are the predominant material for consumer packaging of fruits and vegetables. Besides cost effective materials, automated packaging machines further reduce 
cost of packaging. One of the newest trends in horticultural produce-packaging is the shrink wrapping of individual produce item with polymeric film. Individual shrink wrapping has been studied to package peaches (Bhowmik and Sebris, 1988), citrus (Raghav and Gupta, 2000; Ladaniya et al., 1997; Dhatt et al., 1991), tomato (Hulbert and Bhowmik 1987), pomegranate (Nanda et al., 2001), papaya (Singh and Sudhakar Rao, 2005), guava (Pal et al., 2004) and a variety of tropical and temperate fruits. Shrink wrapping with an engineered plastic wrap can reduce shrinkage, protect the produce from incidence of fungal disease, reduce mechanical damage and provide a good surface for stick - on labels. The use of shrink wrap with polymeric film has a major advantage in reducing moisture losses from the fruit. It also protects the fruit from some damage by abrasion during transport. Drake et al., (1988) investigated the storage quality of 'Delicious' apples individually packaged in rigid film containers. Overall firmness, acidity and soluble solids content decreased over a 70 day storage period. Significant effects of rigid film packaging and storage included; superior skin color, decreased weight loss, slight decrease in soluble solids content and increased firmness loss during ripening when compared to control fruit. They concluded that the atmosphere modified by rigid film container hastened ripening of 'Delicious' apples. The effectiveness of plastic shrink wrap, zip lock bag and vaseline coating was evaluated (Nguyen and Hall 2003) to preserve quality and extend shelf life of apples stored at controlled atmosphere $\left(1.6{ }^{\circ} \mathrm{C}\right)$. In the first two weeks, there were no apparent loss in quality of apples wrapped in zip lock bag and those wrapped in zip lock bag with vaseline coating. Untreated apples had shown a slight reduction in volume, significant bruises and wrinkles and were not marketable after four weeks. The apples wrapped in zip lock bag and zip lock bag with vaselin coating were still marketable after two months in storage. Red Delicious apples after two week of cold storage and after four months of CA storage were packaged individually in heat-shrinkable copolymers and stored at $21^{\circ} \mathrm{C}$ and $50 \% \mathrm{RH}$ represented a shelf life extension of 3-4 weeks over non-packaged controls (Anzueto and Rizvi, 1985). Heaton et al., (1990) reported quality changes in unwrapped and shrink wrapped 'Starkrimson' apple stored at $26^{\circ} \mathrm{C}$ and $40-42 \% \mathrm{RH}$ for thirteen weeks and found shrink wrapped apples to be acceptable throughout storage.

The individual packaging of apple is not practiced in India. The apples imported in carton from the other countries are individually wrapped with netted cushioning cover to reduce bruising during transportation. The present work aimed to evaluate the effectiveness of polymeric film shrink wrap of individual apple fruit and 3 fruits in a tray on the shelf life extension and preservation of overall quality during storage.

\section{Materials and Methods}

\section{Apple fruit and experimental plan}

'Red Delicious' apples which are widely accepted table cultivar were purchased from the wholesale market. At the time of purchase the apples were already packed in wooden boxes and stored in a commercial cold store. Each fruits were visually inspected and sorted; those were free from blemishes, bruises and good in appearance were selected for the experiments. Selected fruits were wiped to clean thoroughly by soft cotton cloth. The following treatments were made to conduct shrink wrapping and to evaluate their effect on quality and shelf life during ambient storage.

R1 - Individual fruit shrink wrapped in 15 micron film 
R2 - Individual fruit shrink wrapped in 25 micron film

R3 - 3 fruits in tray shrink wrapped in 15 micron film

R4 - 3 fruits in tray shrink wrapped in 25 micron film

C - Control sample, without any wrap

\section{Shrink wrapping of apples and storage environment}

Individual pieces of fruit were enclosed in heat shrinkable polyolefin film of 15 and 25 micron thickness separately. Polystyrene trays were used for making 3 fruits in one packaging and they were also enclosed in heat shrinkable polyolefin film of the same thicknesses.

The film envelopes containing fruits was heat sealed with impulse heat sealer. The filmenclosed individual fruits and 3 fruits in trays were passed through a heat shrink tunnel (6.0 $\mathrm{kW}$, Sevana India) at an air temperature of $170^{\circ} \mathrm{C}$ for $15-17 \mathrm{sec}$ with moving belt speed of $5.0 \mathrm{~cm}$ per sec to form a skin tight wrap around the individual fruit surface and over 3 fruits in tray.

The shrink wrapped samples including control were collected treatment wise separately in open mouth corrugated fiber board (CFB) boxes and the boxes were kept at ambient condition $\left(30-38^{\circ} \mathrm{C}, 52-58 \% \mathrm{RH}\right)$ for four weeks storage. Stored apples were tested every week to examine the changes in appearance by visual observation, weight loss due to desiccation (physiological loss in weight, PLW), firmness, titrable acidity expressed as malic acid, total soluble solids (TSS), water activity $\left(\mathrm{a}_{\mathrm{w}}\right)$, decay, instrumental colour $\left(\mathrm{L}^{*}, \mathrm{a}^{*}, \mathrm{~b}^{*}\right)$ and organoleptic test at 9.0 point hedonic scale.

\section{Quality evaluation of apples}

The average size ( 3 dimension perpendiculars to each other) and weight of apple were taken using a Vernier caliper $( \pm 2.0 \mathrm{~mm})$ and an electronic balance $( \pm 2.0 \mathrm{~g})$ respectively prior to shrink wrapping. Selected pieces of wrapped and unwrapped samples were leveled for determination of weight loss due to physiology/desiccation. The leveled fruits were weighed initially and at weekly interval and PLW were determined in \%. All the treatment samples were visually observed for exterior appearance and decay. The decayed samples were removed from the lot and observations were recorded in terms of $\%$ cumulative. A hand held penetrometer/fruit pressure tester (model FT 327; 3-27 lbs with another scale in $\mathrm{kg}$, Italy make) having plunger diameter of $8.0 \mathrm{~mm}$ was used for measurement of skin firmness of apples (average of 3 locations on the fruit surface). The juice was extracted with hand press and filtered properly with muslin cloth for measurement of TSS. A hand held digital refractometer (PAL-1, Atago, Japan, 0-53 ${ }^{\circ}$ brix) was used in which one drop of clear juice gave the direct reading of TSS. Titrable acidity of filtered apple juice was determined by using $0.1 \mathrm{~N} \mathrm{NaOH}$ and expressed as equivalent to malic acid (Ranganna, 1986). Water activity was determined by water activity meter (ROTRONIC Probe type HygroLab3, UK) which has an operating range of humidity $0-100 \%$ and temperature 5$50{ }^{\circ} \mathrm{C}$. Skin colour of apples in terms of $\mathrm{L}^{*}$, $a^{*}, b^{*}$ values of CIE system were recorded by a pre-calibrated handy colourimeter (NR3000, Nippon Denshoku Ind Co Ltd, Japan) where, ' $\mathrm{L}^{*}$ ' indicates lightness, ' $\mathrm{a}$ ' chromaticity on green (-) to red (+) axis and ' $\mathrm{b}$ *' chromaticity on a blue (-) to yellow (+) axis. The apple fruits were subjected for organoleptic test at the beginning and at end of 4 week storage in view to see the overall effect of shrink wrap on its acceptability by 
the consumer. A sensory panel of 10 nontrained panelists evaluated the general appearance and eating quality of apple.

\section{Results and Discussion}

\section{Effect of shrink wrapping on weight loss, decay and firmness}

Shrink wrapping of apple fruit considerably reduced the weight loss during storage. At the end of $4^{\text {th }}$ week, $1.85 \%$ of weight loss was recorded in individual shrink wrapped apples with 25 micron film thickness and that was minimum in comparison to $3.35 \%$ in 15 micron film wrapped. The non-wrapped fruit lost $8.84 \%$ weight during the same period (Fig.1). In case of 3 fruit wrapped in trays with 15 and 25 micron film, weight loss was found 2.64 and $2.52 \%$ respectively. The loss of moisture from the fruit during storage is a physiological phenomenon and it depends on the respiration characteristics of fruit type. Polymeric film wrapping over the fruit created a barrier between fruit surface and environment, resulting in conservation of moisture within the fruit. The loss of water vapour from fruit depends on the film thickness and its ability to transmit vapour into the environment. However, in this case non-significant effect $(\mathrm{P}>0.05)$ of film thickness has been found on weight loss. While comparing the weight loss of shrink wrapped fruit with control sample i.e. unwrapped; the effect of wrapping was found significant $(\mathrm{P}<0.05)$. Reduction in weight loss by shrink wrapping has also been reported by Miller et al., (1983) in mango, Ladaniya et $a l .$, (1997) in Nagpur Mandarins and Nanda et al., (2001) in pomegranate. In control samples, shriveling of fruit skin/peel was prominent due to higher weight loss. The appearance was impaired after first week which was more visible after second week of storage in control samples. On the other hand, the wrapped fruit either individual or in tray wrapped maintained wholesome appearance at the end of fourth week of storage. Water moves from fruit to surrounding atmosphere in the form of water vapour that is higher vapour pressure inside the fruit to the lower vapour pressure in surrounding atmosphere. The rapid migration depends on natural barrier created by fruit epidermis (skin) and waxy cuticle. The microclimate created between the film-wrapping and fruit skin was of high RH that maintained the wholesome appearance of apple even after fourth week. The control samples of apple started decaying after the first week of storage. Over $35 \%$ of fruits were lost at the end of fourth week as compared to 15 and $18 \%$ in samples wrapped with 25 micron film individually and 3 fruits in tray respectively (Fig. 3). The performance of both 15 and 25 micron film was good both in individual fruit wrapping and in tray wrapping of 3 fruits. However 25 micron film thickness showed comparatively better performance as judged visually. Fruits generally lose their firmness during storage due to loss of hydrostatic pressure resulting from respiration process and moisture loss. Figure 2 depicts the loss of firmness in all treatments. Shrink wrapping considerably maintained the firmness of apples during the period of storage. In fruits wrapped in 25 micron film, the firmness was maintained well up to the end of storage period as compared to 15 micron film wrapped. The non-wrapped fruits become shriveled, desiccated and soften after 2 weeks. Similar observation on loss of firmness was reported during storage of different cultivars of apple (Chai et al., 1991).

\section{Effect of shrink wrapping on acidity, TSS and water activity}

The acidity decreased in almost all samples during the period of storage (Table 2). However, it was not significantly different $(\mathrm{P}>0.05)$ in the control and the fruits wrapped 
individually and in trays. It was noted that shrink wrapping did not change the acidity of apples considerably. However as per general trend, acidity may decrease if the fruit was stored for prolonged duration. The values of TSS were also found to be almost constant in wrapped samples during the storage period. In control sample, TSS value slightly increased at the end of fourth week; that may be attributed partly to moisture loss from fruits and consequently an increased concentration of soluble sugars (Table 3). Water activity reduced to the minimum extent in control sample at the end of forth week. The water activity went on decreasing in all treatment samples (Table 4) which attributed to prevailing desiccation during the storage period. The higher moisture loss or weight loss occurred in control sample that lowered the water activity. The effect of film thickness and wrapping either individually or in tray was not significant $(\mathrm{P}>0.05)$ on water activity when compared with the control one.

\section{Effect of shrink wrapping on colour change and sensory score}

The observation on instrumental colour values in terms of $\mathrm{L}^{*}, \mathrm{a}^{*}$ and $\mathrm{b}^{*}$ of the treatment samples are presented in Table 5. In general it was observed that shrink wrapping over the fruit surface maintained good colour throughout the duration of storage. The lightness/glossiness of the apples was also protected by shrink wrapping. The $b^{*}$ value (chromaticity on green (-) to red (+)) decreased more in control sample at the end of forth week. However, it was nonsignificant $(\mathrm{P}>0.05)$ as compared to wrapped fruit either individual or 3 fruits in trays.

Fig.1 Effect of shrink wrapping and storage duration on weight loss (PLW); $n=3$

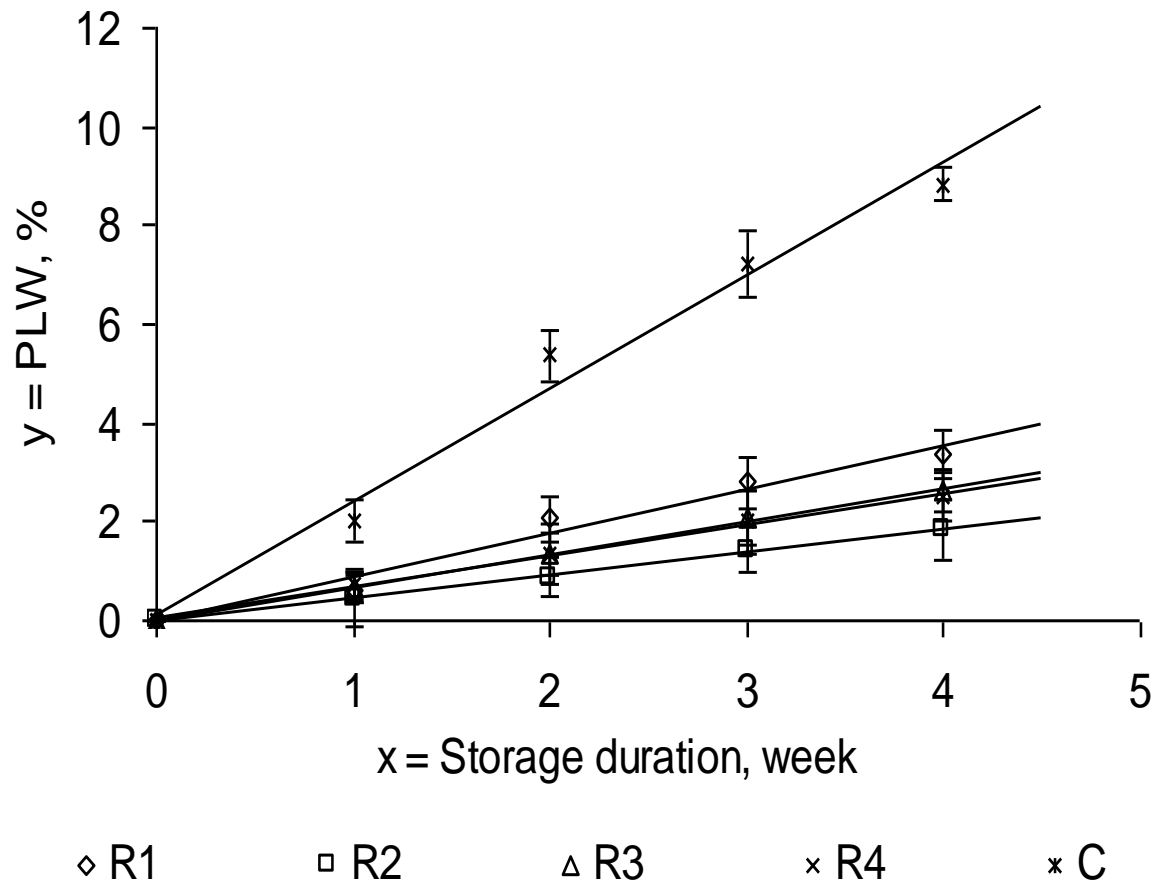

$\mathrm{R} 1 ; \mathrm{y} 1=0.888 \mathrm{x}-0.005 ; \mathrm{R}^{2}=0.974, \quad \mathrm{R} 2 ; \mathrm{y} 2=0.469 \mathrm{x}-0.015 ; \mathrm{R}^{2}=0.998$

$\mathrm{R} 3 ; \mathrm{y} 3=0.667 \mathrm{x}+0.016 ; \mathrm{R}^{2}=0.999, \mathrm{R} 4 ; \mathrm{y} 4=0.632 \mathrm{x}+0.045 ; \mathrm{R}^{2}=0.998$

$\mathrm{C} ; \mathrm{yo}=2.290 \mathrm{x}+0.109 ; \mathrm{R}^{2}=0.984$ 
Fig.2 Effect of shrink wrapping and storage duration on firmness

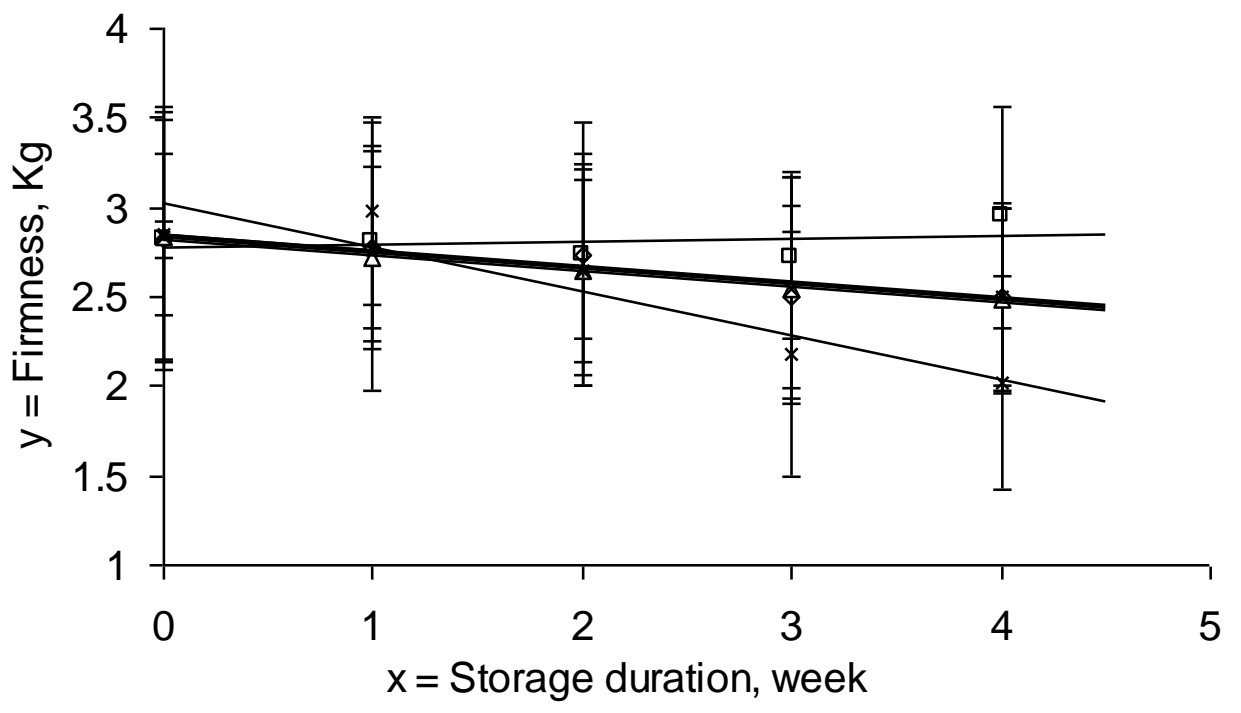
$\diamond \mathrm{R} 1$
$\square \mathrm{R} 2$
$\Delta \mathrm{R} 3$
$\times \mathrm{R} 4$
$* \mathrm{C}$

$\mathrm{R} 1 ; \mathrm{y} 1=-0.092 \mathrm{x}+2.852 ; \mathrm{R} 2=0.870, \mathrm{R} 2 ; \mathrm{y} 2=0.018 \mathrm{x}+2.770 ; \mathrm{R} 2=0.099$

$\mathrm{R} 3 ; \mathrm{y} 3=-0.089 \mathrm{x}+2.826 ; \mathrm{R} 2=0.991, \mathrm{R} 4 ; \mathrm{y} 4=-0.087 \mathrm{x}+2.832 ; \mathrm{R} 2=0.987$

$\mathrm{C} ; \mathrm{y} 0=-0.246 \mathrm{x}+3.028 ; \mathrm{R} 2=0.862$

Fig.3 Effect of shrink wrapping and storage duration on cumulative decay loss

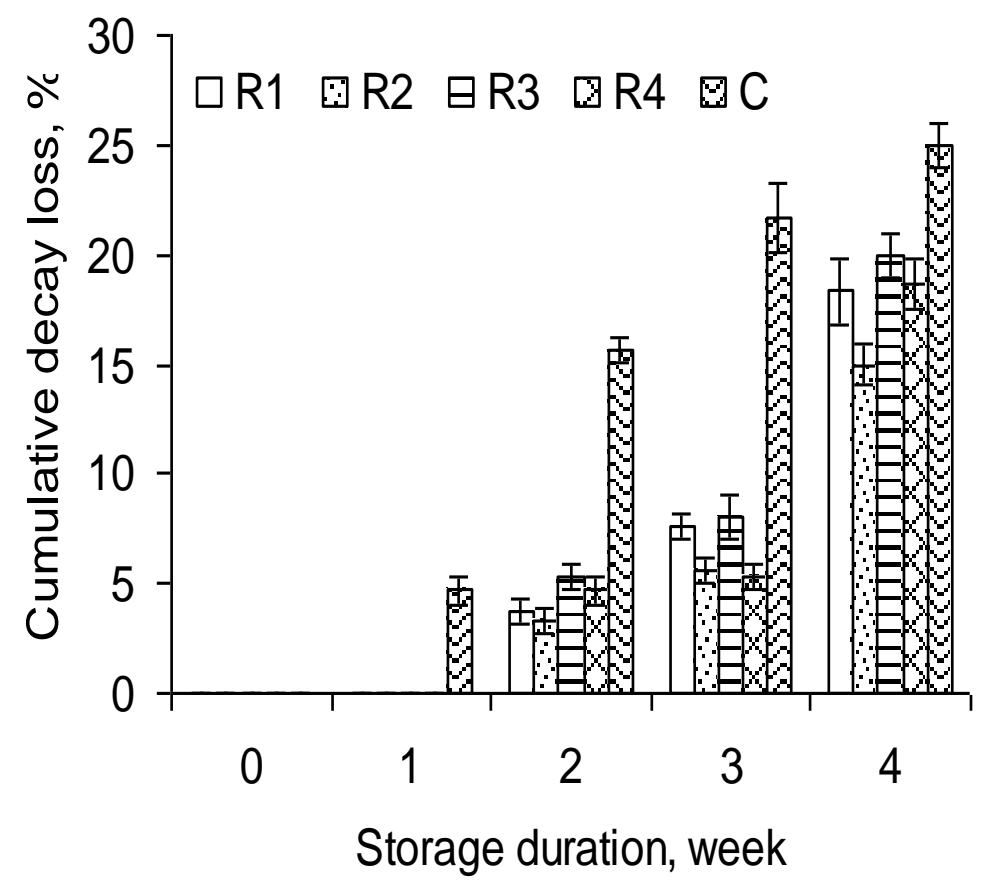


Table.1 Initial physico-chemical quality of 'Red Delicious' apple

\begin{tabular}{ll}
\hline Parameters & Value \pm SD \\
\hline Size distribution & \\
\multicolumn{1}{c}{ Large (L, W, D), cm; $\mathrm{n}=5$} & $9.5 \pm 0.12 ; 9.2 \pm 0.23 ; 8.4 \pm 0.14$ \\
\multicolumn{1}{c}{ Medium (L, W. D), cm; $\mathrm{n}=5$} & $8.4 \pm 0.10 ; 8.3 \pm 0.13 ; 8.2 \pm 0.10$ \\
$\quad$ Small (L, W, D), cm; n=5 & $7.2 \pm 0.18 ; 7.2 \pm 0.09 ; 7.2 \pm 0.10$ \\
Average weight, g; $\mathrm{n}=10$ & $236.6 \pm 44.21$ \\
Total soluble solids, ${ }^{\circ} \mathrm{B} ; \mathrm{n}=3$ & $17 \pm 0.5$ \\
Acidity, \%; $\mathrm{n}=3$ & $0.28 \pm 0.01$ \\
Water activity; $\mathrm{n}=3$ & $0.95 \pm 0.01$ \\
Firmness, kg; $\mathrm{n}=3$ & $2.8 \pm 0.26$ \\
Dry matter content, \%; $\mathrm{n}=3$ & $15.0 \pm 0.45$ \\
Colour, $\mathrm{L}^{*}, \mathrm{a}^{*}, \mathrm{~b} * \mathrm{~b}=10$ & $48.5 \pm 7.3,32.7 \pm 10.8,25.3 \pm 6.8$
\end{tabular}

Table.2 Effect of shrink wrap on acidity of stored apple

\begin{tabular}{lccccc}
\hline Treatment & \multicolumn{5}{c}{ Storage period, week } \\
\cline { 2 - 6 } & 0 & 1 & 2 & 3 & 4 \\
\hline R1 & $0.28 \pm 0.001^{\mathrm{a}}$ & $0.27 \pm 0.002^{\mathrm{a}}$ & $0.26 \pm 0.002^{\mathrm{b}}$ & $0.26 \pm 0.002^{\mathrm{b}}$ & $0.25 \pm 0.002^{\mathrm{b}}$ \\
$\mathrm{R} 2$ & $0.28 \pm 0.003^{\mathrm{a}}$ & $0.27 \pm 0.002^{\mathrm{a}}$ & $0.27 \pm 0.002^{\mathrm{b}}$ & $0.27 \pm 0.001^{\mathrm{a}}$ & $0.27 \pm 0.002^{\mathrm{a}}$ \\
R3 & $0.28 \pm 0.001^{\mathrm{a}}$ & $0.27 \pm 0.001^{\mathrm{a}}$ & $0.27 \pm 0.001^{\mathrm{b}}$ & $0.27 \pm 0.001^{\mathrm{a}}$ & $0.27 \pm 0.002^{\mathrm{a}}$ \\
R4 & $0.28 \pm 0.000^{\mathrm{a}}$ & $0.27 \pm 0.001^{\mathrm{a}}$ & $0.28 \pm 0.001^{\mathrm{a}}$ & $0.27 \pm 0.001^{\mathrm{a}}$ & $0.26 \pm 0.002^{\mathrm{b}}$ \\
$\mathrm{C}$ & $0.28 \pm 0.002^{\mathrm{a}}$ & $0.27 \pm 0.001^{\mathrm{a}}$ & $0.27 \pm 0.002^{\mathrm{b}}$ & $0.27 \pm 0.002^{\mathrm{a}}$ & $0.25 \pm 0.002^{\mathrm{b}}$
\end{tabular}

Means followed by same superscripts within a column do not differ significantly $(\mathrm{p} \leq 0.05)(\mathrm{n}=3)$

Table.3 Effect of shrink wrap on total soluble solids (TSS) of stored apple

\begin{tabular}{lccccc}
\hline Treatment & \multicolumn{5}{c}{ Storage period, week } \\
\cline { 2 - 6 } & 0 & 1 & 2 & 3 & 4 \\
\hline R1 & $17.3 \pm 0.20^{\mathrm{a}}$ & $17.3 \pm 0.26^{\mathrm{a}}$ & $17.0 \pm 0.50^{\mathrm{a}}$ & $17.2 \pm 0.20^{\mathrm{a}}$ & $17.2 \pm 0.20^{\mathrm{b}}$ \\
R2 & $17.5 \pm 0.15^{\mathrm{a}}$ & $17.4 \pm 0.10^{\mathrm{a}}$ & $17.1 \pm 0.25^{\mathrm{a}}$ & $17.0 \pm 0.06^{\mathrm{b}}$ & $17.4 \pm 0.26^{\mathrm{b}}$ \\
R3 & $17.3 \pm 0.26^{\mathrm{a}}$ & $17.5 \pm 0.15^{\mathrm{a}}$ & $17.1 \pm 0.21^{\mathrm{a}}$ & $17.0 \pm 0.50^{\mathrm{b}}$ & $17.3 \pm 0.26^{\mathrm{b}}$ \\
R4 & $17.5 \pm 0.06^{\mathrm{a}}$ & $17.4 \pm 0.10^{\mathrm{a}}$ & $17.4 \pm 0.15^{\mathrm{a}}$ & $17.4 \pm 0.17^{\mathrm{a}}$ & $17.3 \pm 0.15^{\mathrm{b}}$ \\
C & $17.3 \pm 0.15^{\mathrm{a}}$ & $17.5 \pm 0.12^{\mathrm{a}}$ & $17.5 \pm 0.15^{\mathrm{a}}$ & $17.6 \pm 0.20^{\mathrm{a}}$ & $18.0 \pm 0.20^{\mathrm{a}}$
\end{tabular}

Means followed by same superscripts within a column do not differ significantly $(\mathrm{p} \leq 0.05)(\mathrm{n}=3)$ 
Table.4 Effect of shrink wrapping on water activity $\left(a_{w}\right)$ of stored apple

Treatment

Storage period, week

\begin{tabular}{llllll}
\hline 0 & 1 & 2 & 3 & 4
\end{tabular}

\begin{tabular}{llllll}
\hline R1 & $0.95 \pm 0.003^{\mathrm{a}}$ & $0.94 \pm 0.001^{\mathrm{a}}$ & $0.91 \pm 0.003^{\mathrm{a}}$ & $0.89 \pm 0.018^{\mathrm{a}}$ & $0.86 \pm 0.002^{\mathrm{a}}$ \\
R2 & $0.95 \pm 0.001^{\mathrm{a}}$ & $0.94 \pm 0.002^{\mathrm{a}}$ & $0.91 \pm 0.002^{\mathrm{a}}$ & $0.90 \pm 0.020^{\mathrm{a}}$ & $0.88 \pm 0.002^{\mathrm{b}}$ \\
R3 & $0.96 \pm 0.002^{\mathrm{b}}$ & $0.94 \pm 0.002^{\mathrm{a}}$ & $0.91 \pm 0.002^{\mathrm{a}}$ & $0.89 \pm 0.004^{\mathrm{a}}$ & $0.87 \pm 0.003^{\mathrm{a}}$ \\
$\mathrm{R} 4$ & $0.95 \pm 0.002^{\mathrm{a}}$ & $0.94 \pm 0.002^{\mathrm{a}}$ & $0.91 \pm 0.002^{\mathrm{a}}$ & $0.91 \pm 0.002^{\mathrm{a}}$ & $0.88 \pm 0.004^{\mathrm{b}}$ \\
$\mathrm{C}$ & $0.95 \pm 0.003^{\mathrm{a}}$ & $0.91 \pm 0.002^{\mathrm{b}}$ & $0.89 \pm 0.002^{\mathrm{b}}$ & $0.88 \pm 0.003^{\mathrm{b}}$ & $0.85 \pm 0.003^{\mathrm{a}}$
\end{tabular}

Means followed by same superscripts within a column do not differ significantly $(\mathrm{p} \leq 0.05)(\mathrm{n}=3)$

Table.5 Effect of shrink wrapping on colour of apple during storage

Storage period, week

\begin{tabular}{llllc}
\hline \multirow{5}{*}{ Treatment } & \multicolumn{4}{c}{ Storage period, week } \\
\cline { 3 - 5 } & & & 2 & \\
\hline & & & & \\
R1 & $\mathrm{L}^{*}$ & $48.5 \pm 2.17^{\mathrm{a}}$ & $51.5 \pm 2.36^{\mathrm{a}}$ & $50.3 \pm 2.21^{\mathrm{b}}$ \\
& $\mathrm{a}^{*}$ & $32.7 \pm 2.54^{\mathrm{a}}$ & $30.6 \pm 5.14^{\mathrm{a}}$ & $24.3 \pm 3.39^{\mathrm{a}}$ \\
& $\mathrm{b}^{*}$ & $25.4 \pm 3.01^{\mathrm{a}}$ & $24.2 \pm 0.35^{\mathrm{a}}$ & $27.0 \pm 2.65^{\mathrm{a}}$ \\
$\mathrm{n} 2$ & $\mathrm{~L}^{*}$ & $48.8 \pm 1.78^{\mathrm{a}}$ & $49.7 \pm 1.90^{\mathrm{b}}$ & $50.4 \pm 2.00^{\mathrm{b}}$ \\
& $\mathrm{a}^{*}$ & $32.5 \pm 1.80^{\mathrm{a}}$ & $31.3 \pm 1.11^{\mathrm{a}}$ & $25.6 \pm 0.96^{\mathrm{a}}$ \\
$\mathrm{R} 3$ & $\mathrm{~b}^{*}$ & $26.4 \pm 1.70^{\mathrm{a}}$ & $25.3 \pm 1.84^{\mathrm{a}}$ & $26.5 \pm 1.05^{\mathrm{a}}$ \\
& $\mathrm{L}^{*}$ & $48.5 \pm 1.12^{\mathrm{a}}$ & $49.9 \pm 3.23^{\mathrm{a}}$ & $52.8 \pm 2.03^{\mathrm{a}}$ \\
& $\mathrm{a}^{*}$ & $33.7 \pm 2.59^{\mathrm{a}}$ & $23.8 \pm 2.27^{\mathrm{b}}$ & $22.7 \pm 3.82^{\mathrm{a}}$ \\
& $\mathrm{b}^{*}$ & $25.4 \pm 2.18^{\mathrm{a}}$ & $25.1 \pm 2.50^{\mathrm{a}}$ & $24.3 \pm 1.14^{\mathrm{a}}$ \\
& $\mathrm{L}^{*}$ & $48.5 \pm 1.05^{\mathrm{a}}$ & $52.8 \pm 1.00^{\mathrm{a}}$ & $54.8 \pm 1.73^{\mathrm{a}}$ \\
& $\mathrm{a}^{*}$ & $32.7 \pm 3.30^{\mathrm{a}}$ & $25.9 \pm 2.30^{\mathrm{a}}$ & $23.9 \pm 3.91^{\mathrm{a}}$ \\
& $\mathrm{b}^{*}$ & $25.4 \pm 2.05^{\mathrm{a}}$ & $23.8 \pm 2.00^{\mathrm{a}}$ & $22.8 \pm 2.43^{\mathrm{b}}$ \\
$\mathrm{C}$ & $\mathrm{L}^{*}$ & $49.5 \pm 2.30^{\mathrm{a}}$ & $49.3 \pm 2.27^{\mathrm{b}}$ & $47.7 \pm 1.11^{\mathrm{b}}$ \\
& $\mathrm{a}^{*}$ & $32.7 \pm 1.92^{\mathrm{a}}$ & $22.6 \pm 2.25^{\mathrm{b}}$ & $18.1 \pm 2.10^{\mathrm{b}}$ \\
& $\mathrm{b}^{*}$ & $25.4 \pm 2.00^{\mathrm{a}}$ & $24.4 \pm 3.49^{\mathrm{a}}$ & $25.6 \pm 2.51^{\mathrm{a}}$
\end{tabular}

Means followed by same superscripts within a column do not differ significantly $(\mathrm{p} \leq 0.05)(\mathrm{n}=3)$ 
Table.6 Sensory score of shrink wrapped apple at initial and $4^{\text {th }}$ week of storage (9.0- Like extremely and 1.0- Dislike extremely)

\begin{tabular}{|c|c|c|c|c|c|c|}
\hline \multirow{2}{*}{ Attributes } & \multirow{2}{*}{ Initial } & \multicolumn{4}{|c|}{ At the end of $4^{\text {th }}$ week } & \multirow[b]{2}{*}{$\mathrm{C}$} \\
\hline & & R1 & $\mathrm{R} 2$ & R3 & $\mathrm{R} 4$ & \\
\hline Colour & $8.0 \pm 0.5^{\mathrm{a}}$ & $7.2 \pm 0.3^{\mathrm{a}}$ & $7.5 \pm 0.3^{\mathrm{a}}$ & $7.0 \pm 0.5^{\mathrm{a}}$ & $7.1 \pm 0.1^{\mathrm{a}}$ & $5.3 \pm 0.6^{b}$ \\
\hline Flavour & $7.5 \pm 0.5^{\mathrm{a}}$ & $6.5 \pm 0.3^{\mathrm{a}}$ & $7.0 \pm 0.2^{\mathrm{a}}$ & $6.5 \pm 0.3^{\mathrm{a}}$ & $6.9 \pm 0.5^{\mathrm{a}}$ & $4.5 \pm 0.5^{b}$ \\
\hline Taste & $7.0 \pm 0.5^{\mathrm{a}}$ & $6.6 \pm 0.4^{\mathrm{a}}$ & $6.8 \pm 0.3^{\mathrm{a}}$ & $6.5 \pm 0.3^{\mathrm{a}}$ & $6.5 \pm 0.3^{\mathrm{a}}$ & $5.5 \pm 0.5^{b}$ \\
\hline Texture & $7.0 \pm 0.5^{\mathrm{a}}$ & $6.5 \pm 0.5^{\mathrm{a}}$ & $6.5 \pm 0.5^{\mathrm{a}}$ & $6.0 \pm 0.2^{\mathrm{a}}$ & $6.2 \pm 0.3^{\mathrm{a}}$ & $3.8 \pm 0.3^{b}$ \\
\hline Overall & $7.5 \pm 0.5^{\mathrm{a}}$ & $6.8 \pm 0.3^{\mathrm{a}}$ & $7.0 \pm 0.5^{\mathrm{a}}$ & $6.5 \pm 0.9^{\mathrm{a}}$ & $7.0 \pm 0.5^{\mathrm{a}}$ & $3.3 \pm 0.6^{b}$ \\
\hline Acceptabil & & & & & & \\
\hline
\end{tabular}

Means followed by same superscripts within a row do not differ significantly $(\mathrm{p} \leq 0.05)(\mathrm{n}=10)$

A good protection of colour and gloss was provided by wrapping of apple with polymeric shrink film. The fruits of different treatments were evaluated for sensory quality at the end of storage period. Initial and final sensory scores were compared (Table 6). Score on overall acceptability revealed better retention of eating quality of apples wrapped in 25 micron film thickness; at the same time 15 micron wrapped fruit was also found to be equally good after fourth week of storage. The quality of unwrapped control sample was not acceptable at the end of storage. In fact the unwrapped control samples lost overall appearance and eating acceptability after the second week.

\section{Cost of shrink wrapping}

A detailed cost analysis of shrink wrapping of individual apple fruit and 3 fruits in polystyrene tray revealed that this technique of minimal processing of fruits to be cost effective. These types of packaging needs a heat shrink tunnel, heat shrinkable polymeric film and impulse heat sealer which are usually available in the market. Cost analysis of shrink wrapping of individual apple fruit and 3 fruits in tray worked out to Rs. $0.50-0.60$ per individual fruit and Rs. 1.50-2.00 per tray of 3 fruits depending on the size of the fruit and film thickness. Shrink wrapped apples with a marginal increase in cost could increase the consumer preference with extended marketable shelf life.

The study demonstrated individual and tray shrink wrapping to increase the marketable shelf life and to maintain the initial quality of apples in comparison to unwrapped apples. A 25 micron film gave better performance during the fourth week of storage at ambient condition. The shrink wrapped apple either individual or in tray with 3 fruits may be a superior proposition for organized retail marketing where minimally processed fruits and vegetables are in good demand. This technology is cost effective and has ability to extend marketable shelf life of apple fruits.

\section{References}

Anzueto, C. R. and Rizvi, S. S. H 1985. Individual packaging of apples for shelf life extension. J. Food Sci., 50, 897900.

Bhowmik, S. R. and Sebris, C. A. M 1988. Quality and shelf life of individually shrink-wrapped Peaches. J. Food Sci., 53, 519-522.

Chai, Y. O. D. B. and Cash, J. N 1991. Shelf life extension of Michigan apples using 
sucrose polyester. J. Food Processing Preser., 15, 197-214.

Dhatt, A. S., Randhawa, J. S. and Singh, S. N 1991. Effects of individual seal packaging in high density polyethylene (HDPE) film on storage life and quality of Kinnow. J. Pl. Sci. Res., 7, 84-85.

Drake, S. R., Fellman, J. K. and Nelson, J. W 1988. Quality of apple fruit in rigid film containers. J. Food Quality, 11, 183191.

Heaton, E. K., Dobson, J. W., Lane, R. P. and Beuchat, L. R. 1990. Evaluation of shrink-wrap packaging for maintaining quality of apples. J. Food Protection, 53, 598-599.

Hulbert, G. J., Bhowmik, S. R. 1987. Quality of fungicide treated and individually shrink wrapped tomatoes. J. Food Sci., 52, 1293-1295.

Ladaniya, M. S., Sonkar, R. K. and Das, H. C. 1997. Evaluation of heat shrinkable film wrapping of Nagpur mandarin (Citrus reticulate Blanco) for storage. J. Food Sci. Technol., 34, 324-337.

Miller, W. R., Hale, P. W., Spalding, D. H. and Davis, P. 1983. Quality and decay of mango fruit wrapped in heatshrinkable film. Hort. Sci., 18, 957-958.

Nanda, S., Sudhakar Rao, D. V., Krishnamurthy, S. 2001. Effects of shrink film wrapping and storage temperature on the shelf life and quality of pomegranate fruits cv. Ganesh. PostHarvest Biol. Technol., 22, 61-69.

Nguyen, C. and Hall, C. 2003. The effects of plastic wrap on the quality of Gala apples in cold storage. American Soc. Agric. Biological Engineers, St. Joseph, Michigan, Paper No. 036126 (www.asabe.org)

Pal, R. K., Ahmad, M. S., Roy, S. K. and Singh, M. 2004. Influence of storage environment, surface coating and individual shrink wrapping on quality assurance of Guava (Psidium guajava) fruits. Pl. Foods Human Nutrition, 59, 67-72.

Raghav, P. K. and Gupta, A. K. 2000. Quality and shelf life of individually shrink wrapped Kinnow fruits. J. Food Sci. Technol., 37, 613-616.

Ranganna, S. 1986. Handbook of analysis and quality control for fruits and vegetables products. McGraw Hill Publ. Co. Ltd., New Delhi.

Singh, S. P. and Sudhakar Rao, D. V. 2005. Quality assurance of papaya by shrink film wrapping during storage and ripening. J. Food Sci. Technol., 42, 523525.

\section{How to cite this article:}

Abhay Kumar Thakur, Ramesh Kumar, Vidya Bhushan Shambhu and Indu Shekhar Singh. 2017. Effectiveness of Shrink-wrap Packaging on Extending the Shelf-life of Apple. Int.J.Curr.Microbiol.App.Sci. 6(12): 2365-2374. doi: https://doi.org/10.20546/ijcmas.2017.612.273 